\title{
DOUBLE THRESHOLD SPECTRUM SENSING WITH OPTIMIZATION OF SAMPLES IN COGNITIVE RADIO NETWORKS
}

\author{
Chilakala Sudhamani \\ Departmentof Electronics and Communication Engineering, \\ CMR Technical Campus, Hyderabad, India \\ Corresponding author: Sudhamani.ece@cmrtc.ac.in
}

(Received: $26^{\text {th }}$ August 2020; Accepted: $12^{\text {th }}$ November 2020; Published on-line: $5^{\text {th }}$ July 2021)

\begin{abstract}
In cognitive radio networks spectrum sensing playsa vital role to identify the presence or absence of the primary user.In conventional spectrum sensing one secondary user will makea final decision regarding the availability of licensed spectrum.But Secondary user fail to make a correct detection about thepresence of the primary user if he is in fading environmentand it causes interference to the licensed users. Therefore toavoid interference to the licensed users and to make correct detection, number of samples is increased, Which increases theprobability of detection. In this paper the optimization of samplesis proposed to reduce the system overhead and also to increase thepropagation time. Simulation results show the optimized valueof samples for a given probability of false alarm and also thevariation of probability of detection with optimized samples andfalse alarm is shown in the results.
\end{abstract}

\begin{abstract}
ABSTRAK:Dalam rangkaian radio kognitif, penginderaan spektrum memainkan peranan penting untuk mengenal pasti kehadiran atau ketiadaan pengguna utama. Dalam penginderaan spektrum konvensional, seorang pengguna sekunder akan membuat keputusan akhir mengenai ketersediaan spektrum berlesen. Tetapi pengguna Sekunder gagal membuat pengesanan yang betul mengenai kehadiran pengguna utama jika dia berada dalam persekitaran yang pudar dan menyebabkan gangguan kepada pengguna yang berlesen. Oleh itu untuk mengelakkan gangguan kepada pengguna berlesen dan membuat pengesanan yang betul, jumlah sampel meningkat, yang meningkatkan kemungkinan pengesanan. Dalam makalah ini pengoptimuman sampel dicadangkan untuk mengurangi overhead sistem dan juga untuk meningkatkan waktu penyebaran. Hasil simulasi menunjukkan nilai sampel yang dioptimumkan untuk kebarangkalian penggera palsu dan juga variasi kebarangkalian pengesanan dengan sampel yang dioptimumkan dan penggera palsu ditunjukkan dalam hasil.
\end{abstract}

KEYWORDS: Cognitive radio; spectrum sensing; detection threshold; optimization

\section{INTRODUCTION}

Due to the increased use of $3 \mathrm{G}$ and $4 \mathrm{G}$ mobile servicesand accelerated use of wireless internet services, there is asoaring demand for radio frequency available for wirelesscommunication. For utilizing particular frequency bandlicenses are required. In every country these licenses areauctioned by the governing agencies like Department of Telecommunication (DoT) in India, Federal CommunicationsCommission (FCC) in USA, etc. and assigns to licensed usersor Primary Users (PUs). However, research conducted by FCC concluded that the actual dispute is not limited bandwidth but improper usage of available spectrum, and also a largeamount of band is underused [1] by the licensed users. 
When the spectrum is not occupied by the PU then it is termed as spectrum holes. This problem can be solved with the help of Cognitive Radio (CR) concept [2].

The main focus of cognitive radio is to select wireless spectrum dynamically without disturbing primary user and in accordance to that its transmission and reception parameters changes. This selection of spectrum which is available for communication is done by spotting the presence of PUs and enables Secondary Users (SUs) without disturbing PU communication. This process of selection is known as spectrum sensing [3]. Spectrum sensing techniques are divided into three major categories: Matched filter method, Energy detection method and Future detection. These three methods have its own pros and cons [46]. Energy detection method is having more advantages compared to remaining methods because of its simple architecture but the only problem is at low signal to noise ratio (SNR). Double threshold method has been proposed to overcome low SNR [7-10]. In conventional spectrum sensing, the single cognitive radio is used to detect the presence of primary users which may cause problems like fading, shadowing, and uncertainty [11-13]. In cooperative spectrum sensing, the sensing is done with the cooperation data given by multiple SUs. These individual decisions are combined and come to a single conclusion about the presence or absence of primary users at the fusion center with the help of fusion rules. But in CSS, the energy consumption increases with the increased number of SUs.

The accuracy of detection can be analyzed by two probabilities: the probability of detection and the probability of false alarm. Probability of detection represents that the CR is deciding that the primary user is present when he is actually present i.e. spectrum is busy. Where as CR is represented with the probability of false alarm when the report given by CR is that PU is present when PU is absent. Probability of false alarm will affect system efficiency because the user will not use the free band [14-15]. In [16], the authors used multitaper spectrum estimation to give a closed-form expression for the probability of detection and false alarm. By comparing multitaper spectrum estimation with an energy detector, authors concluded that energy detector requires more number of samples to attain the same detection and false alarm probabilities.

The performance analysis is given by the author in [17] for accurate detection of different hard and soft fusion rules in a real scenario. Authors explained about the randomness of signal to noise ratio in the real environment. The author in [18], derived the probability of miss detection in Eigen ratio spectrum sensing using a random matrix theory approach. The mathematical expression derived as a function number of CR, samples, and signal to noise ratio of PU. In [19], the authors proposed a two stage spectrum sensing technique compared with existing models for varying SNR. In this paper we proposed optimization of samples to reduce the system overhead and to increase the overall detection probability.

\section{SYSTEM MODEL}

In cognitive radio networks, spectrum sensing plays an important role and in this paper we considered energy detection method as suitable one for increasing the detection performance because of its advantages. Block diagram of energy detection method is shown in Fig. 1.

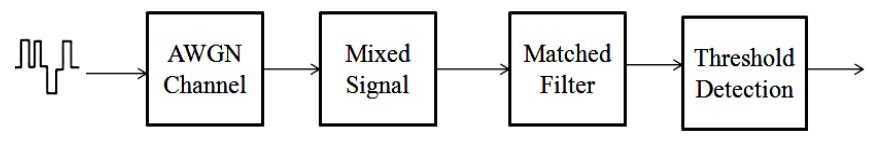

Fig. 1: Block Diagram of Conventional Energy Detection Method 
Incoming signal is passed through band pass filter to reduce the noise and then it is squared and integrated to get total signal energy. The received energy is compared with the predefined threshold value to identify the presence or absence of the PU.This is done through hypothesis testing, if $\mathrm{PU}$ is present then it is represented by $H_{l}$ else it is represented by $H_{0}$.

$$
\begin{array}{ll}
x(n)=p(n)+w(n) & : H_{1} \\
x(n)=w(n) & : H_{0}
\end{array}
$$

Where $p(n)$ is a PU signal, $w(n)$ is a Gaussian noise and $x(n)$ is a received signal respectively. Energy of a signal is estimated through number of samples and is given by $[8,18]$.

$$
Y(n)=\sum_{n=1}^{N}|x(n)|^{2}
$$

Where $N$ represents the number of samples used to estimate the total energy of a signal. Decision statistics of spectrum sensing are probability of detection $\left(p_{d}\right)$ and probability offalse alarm $\left(p_{f}\right)$, which are given by [18]

$$
\begin{gathered}
p_{d}=\operatorname{Prob}\left(Y>T \mid H_{1}\right)=Q\left(\frac{T-N\left(\sigma_{p}^{2}+\sigma_{w}^{2}\right)}{\sqrt{2 N\left(\sigma_{p}^{2}+\sigma_{w}^{2}\right)^{2}}}\right) \\
p_{f}=\operatorname{Prob}\left(Y>T \mid H_{0}\right)=Q\left(\frac{T-N\left(\sigma_{w}^{2}\right)}{\sqrt{2 N\left(\sigma_{w}^{2}\right)^{2}}}\right)
\end{gathered}
$$

Where $T$ is detection threshold with which the received energy of SU is compared with to make a final decision about the presence or absence of the PU.

For a fixed false alarm probability, detection threshold is calculated from equation (5) as

$$
Y(n)=\sum_{n=1}^{N}|x(n)|^{2}
$$

In Eq.(3), the number of samples used to estimate the energy of a given signal determines the system performance. For large number of samples the performance is good compared to the less number of samples which is shown in the Fig. 2. As the number of samples increases detection probability increases because more number of samples gives more accurate values, same can be observed from this figure.

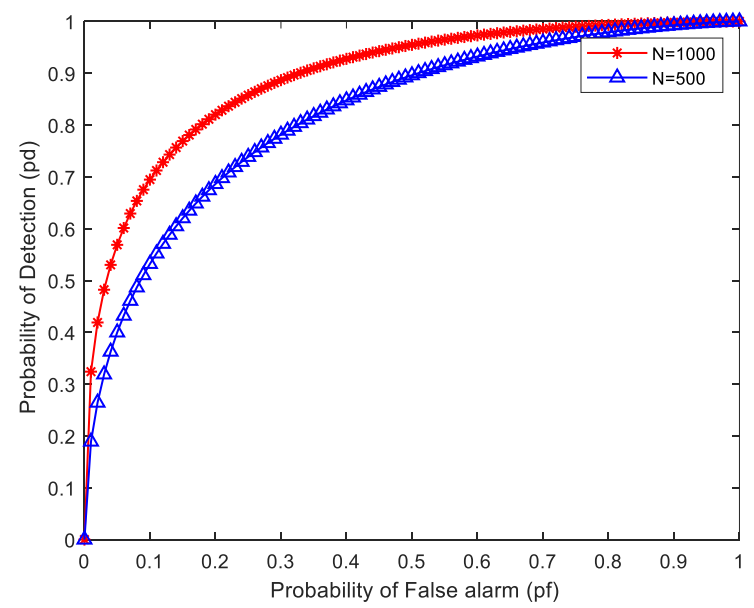

Fig. 2: Probability of detection with probability of false alarm. 
Detection threshold, probability of detection and probability of false alarm depends on the number of samples. If the number of samples is go on increasing to increase the performance of a system then the processing time increases which leads to more overhead on this system. The time taken to estimate the detection threshold, probability of detection and false alarm increases, which may cause spectrumun-utilization. If the spectrum is actually free and same is identified by the SU after long processing time then it causes spectrum wastage i.e. no one is going to utilize it and also with in the estimation time of SU, if primary user want to use then SU may cause interference to the PU by accessing the spectrum.

Therefore, to overcome this problem, number of samples used to estimate the detection probability is optimized in this paper. These optimized numbers of samples are estimated by maximizing the detection threshold. Differentiating Eq.(6) and equating to zero gives the optimal number of samples, which is given as

$$
\frac{d T}{d N}=\frac{d}{d N}\left(\sigma_{w}^{2}\left(N+\sqrt{2 N}\left(Q^{-1}\left(p_{f}\right)\right)\right)=0\right.
$$

After differentiation it gives the optimal number of samplesas

$$
N_{o p t}=\frac{1}{\sigma_{w}^{4}\left(Q^{-1}\left(p_{f}\right)\right)^{2}}
$$

Optimized number of samples increases the processing time and reduces the system over head. This increases the system performance and also spectrum utilization. Now the proposed threshold is given as

$$
T_{\text {opt }}=\sigma_{w}^{2}\left(N_{\text {opt }}+\sqrt{2 N_{o p t}}\left(Q^{-1}\left(p_{f}\right)\right)\right.
$$

In Eq. (9) new detection threshold is estimated toincrease the detection probability. To further improve thedetection probability, double threshold method has been proposed. Figures 3 and 4 show the conventional and proposed double threshold spectrum sensing methods.

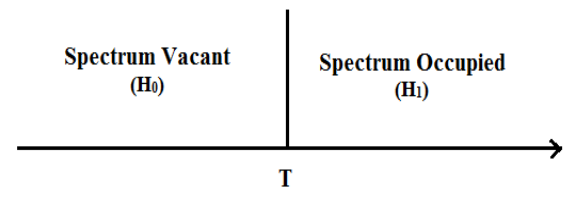

Fig. 3: Conventional spectrum sensing.

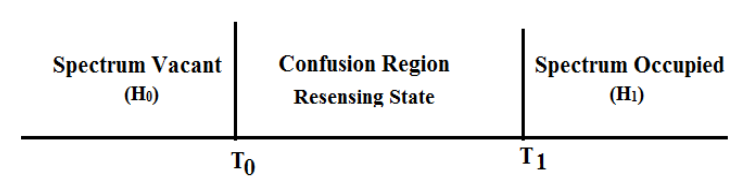

Fig. 4: Double threshold spectrum sensing.

In the double threshold spectrum sensing new thresholds are given as $\left(T_{0}\right)$ and $\left(T_{1}\right)$. If the received signal is less than the detection threshold $\left(\mathrm{T}_{0}\right)$ then the PU is declared as absent. If the received is greater than the detection threshold $\left(T_{1}\right)$ then PU is present. If the received signal lies between $\left(T_{0}\right)$ and $\left(T_{1}\right)$ then $\mathrm{SU}$ will re-sense the spectrum. This method reduces themiss detection and false alarm probabilities. New detection thresholds are given as

$$
\begin{aligned}
& T_{1}=T_{o p t}+K T_{o p t} \\
& T_{0}=T_{o p t}-K T_{o p t}
\end{aligned}
$$

Where $K$ represents the improvement factor of detection threshold. 


\section{SIMULATION RESULTS}

In this paper we considered optimization of number of samples and double threshold method. Figure 5 shows the relation between optimal number of samples and probability of false alarm. From this figure it is observed that the optimal $N$ value decreases as the $p f$ increases from 0 to 0.5 and thenit increases as pf increases from 0:5 to 1 . This also showsthat the optimal false alarm is 0.5 . At this point we need less number of samples to increase the detection probability.

Figure 6 shows the variation of pd with respective to $p f$ for variable improvement factor $K$. The factor $K$ is varied from $5 \%$ to $50 \%$. From this figure it is observed that the detection probability is high for small values of $K$ because the upper threshold is small for small values of $K$ and it is easy to identify the PU presence or absence. As $K$ increases, upper threshold increases which reduces the detection probability. Therefore we can use small improvement factor for increasing the detection probability. From this figure also it is observed that the optimal $p_{f}$ is 0.5 .

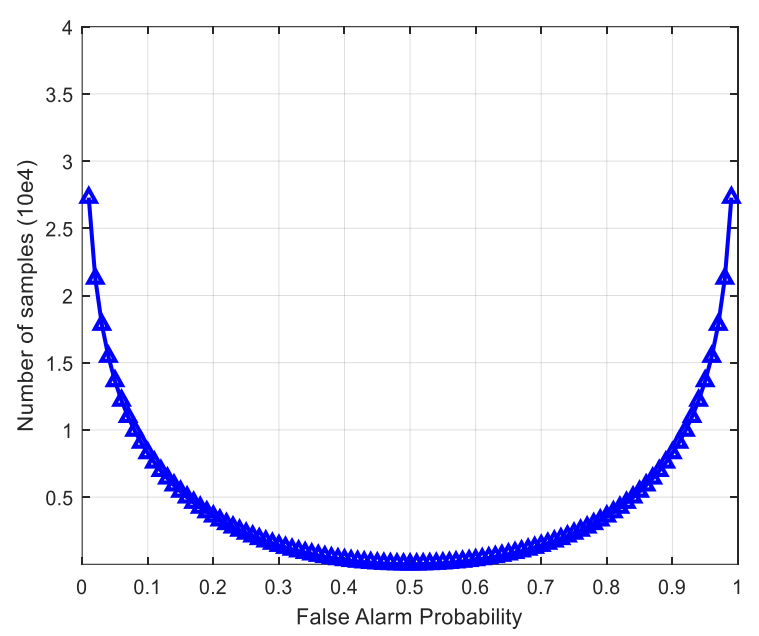

Fig. 5: Optimized samples with probability of false alarm.

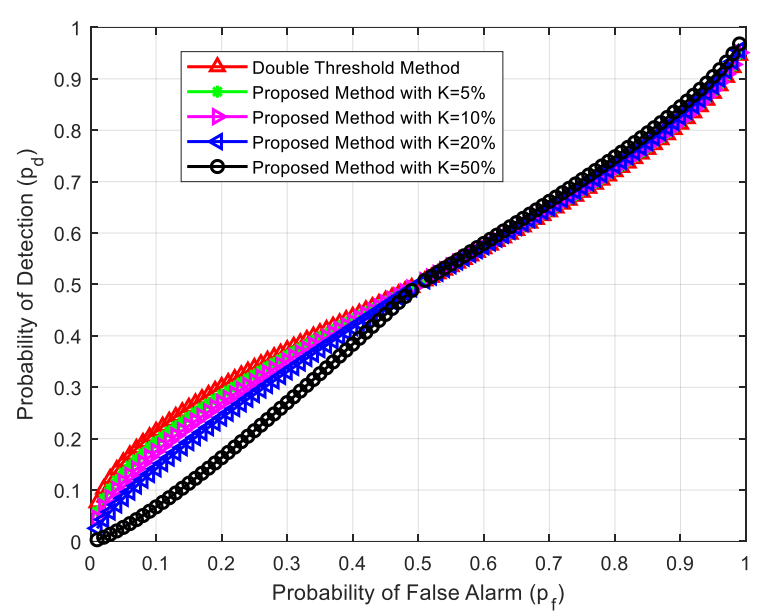

Fig. 6: Probability of detection with probability of false alarm using $K$.

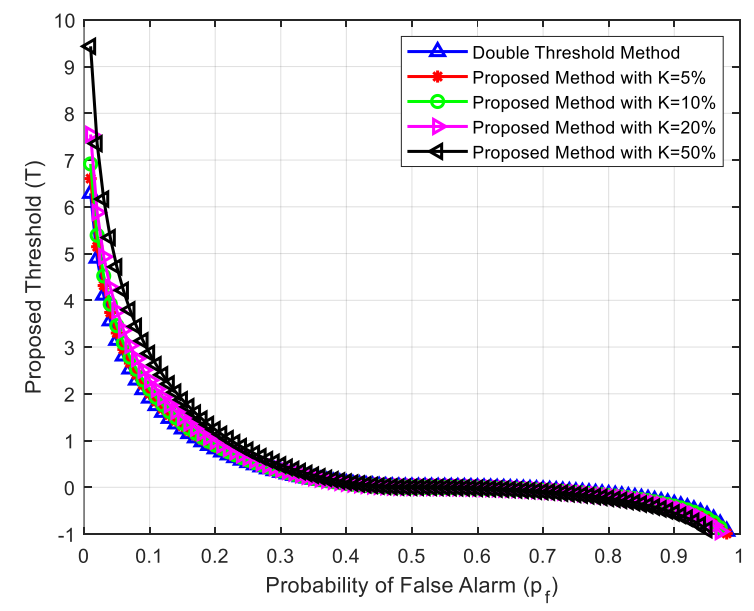

Fig. 7: Detection threshold with probability of false alarm.

Figure 7 shows the variation of threshold with false alarm. Threshold is high at low $p_{f}$, because the spectrum sensing depends on detection threshold. At low detection threshold 
probability of false alarm is high which is also shown inthe figure. So, we need high detection thresholds to improve the system performance. With the improvement factor thethreshold value decreases for a given $p_{f}$.

From the three figures it is observed that the optimal falsealarm is 0:5. Which is used to increase the overall system performance and the optimal number of samples required isalso less at this $p_{f}$. This reduces the overhead on the system and time taken to conclude the presence or absence of the PU.

\section{CONCLUSION}

In this paper, we estimated the probability of detection with variable number of samples and false alarm. From the results it is observed that the detection probability is high for large number of samples. But it increases the sensing and decision making time. So to reduce this optimization of samples has been proposed in this paper. The optimal samples and optimal false alarm are estimated from the results, which improves the detection performance and also reduces the processing time and system overhead. This increases the overall spectrum usage than compared to the conventional method.

\section{ACKNOWLEDGEMENT}

This work is supported by grant no.SR/FST/College 017/2017 under DST FIST program2017, received by the Department of Electronics \&Communication Engineering, CMR Technical Campus, Hyderabad.

\section{REFERENCES}

[1] Federal Communications Commission. (2002) Spectrum policy task force. ET Docket No. 02-35.

[2] Sharma V, Joshi S. (2018) A literature review on spectrum sensing in cognitive radio applications. Second International Conference on Intelligent Computing and Control Systems: July 2018.

[3] Mitola J, Maguire MG. (1999) Cognitive radio: Making software radios more personal. IEEE Personal Communications, 6:13-18.

[4] Cabric D, Mishra SM, Brodersen RW. (2004) Implementation issues in spectrum sensing for cognitive radios. Proceedings of Asilomar Conference on Signals, Systems, and Computers, 1:772-776.

[5] Yucek T, Arslan D. (2009) A survey of spectrum sensing algorithms for cognitive radio applications. IEEE Communications Surveys and Tutorials, 11:116-130.

[6] Ali SS, Liu C, Jin M. (2014) Minimum eigenvalue detection for spectrum sensing. International Journal of Electrical and Computer Engineering (IJECE), 4:623-630.

[7] Liu SQ, Hu BJ, Wang XY. (2012) Hierarchical cooperative spectrum sensing based on double thresholds energy detection. IEEE Communications Letters, 16:1096-1099.

[8] Xie J, Chen J. (2012) An adaptive double threshold spectrum sensing algorithm under noise uncertainty. Computer and Information Technology, 1:824-827.

[9] Ribas ADOP, Dias US. (2015) On the double threshold energy detection-based spectrum sensing over fading channel. Radio and Wireless Symposium: 2015, San Diego, CA.

[10] Steve Arul U, Salai Chandira Rajan S. (2016) Spectrum management techniques using cognitive radios. Cognitive Radio Technology: International Journal of Data Mining Techniques and Applications, 5: 79-82.

[11] Ganesan G, Li YG. (2007) Cooperative spectrum sensing in cognitive radio-part I: two user networks. IEEE Transaction on Wireless Communications, 6: 2204-2213 
[12] Christian I, Sangman M, Chung I, Lee J. (2012) Spectrum mobility in cognitive radio networks. IEEE Communications Magazine, 50(6): 114-121.

[13] Xuping Z, Jianguo P. (2007) Energy-detection based spectrum sensing for cognitive radio. IET Conference on Wireless, Mobile and Sensor Networks: 944-947.

[14] Lee SH, Oh DC, Lee YH. (2009) Hard decision combining based cooperative spectrum sensing in cognitive radio systems. International Conference on Wireless Communications and Mobile Computing: 2009, Leipzig, Germany. 906-910.

[15] Hou F, Chen X, Huang H, Jing X. (2016) Throughput performance improvement in cognitive radio networks based on spectru prediction. 16th International Symposium on Communications and Information Technologies: Qingdao, China.

[16] Wu J, Luo T, Li J, Yue G. (2009) A cooperative double threshold energy detection algorithm in cognitive radio systems. IEEE International Conference on Wireless Communication, Networking \& Mobile Computing., 1-4. doi10.1109/WICOM.2009.5303377

[17] Owayed A, Mohammed ZA, Mosa AA. (2010) Probabilities of detection and false alarm in multitaper based spectrum sensing for cognitive radio systems in AWGN. IEEE International Conference on Communication Systems: 2010 Singapore. 579-584.

[18] Verma P, Singh B. (2015) Simulation study of double threshold energy detection method for cognitive radios. 2nd International Conference on Signal Processing and Integrated Networks: Noida. 232- 236.

[19] Sengupta A, Chattopadhyay S, Ghatak SR, Biswas V. (2019) Two-Stage spectrum sensing model for varying SNR conditions in cognitive radio network. International Conference on Electrical, Electronics and Computer Engineering: ALIGARH, India. 